\title{
Microstructure of industrially produced reduced and low fat Turkish white cheese as influenced by the homogenization of cream
}

\author{
By A.D. Karaman ${ }^{a *}$, M. Benli ${ }^{\mathrm{b}}$ and A.S. Akalın ${ }^{\mathrm{c}}$ \\ ${ }^{a}$ Adnan Menderes University, Faculty of Agriculture, Department of Food Engineering, Aydın, Turkey \\ ${ }^{b}$ Ankara University, Faculty of Science, Department of Biology, Ankara, Turkey \\ ${ }^{\circ}$ Ege University, Faculty of Agriculture, Department of Dairy Technology, Izmir, Turkey \\ *Corresponding author: demet.karaman @ adu.edu.tr
}

\section{RESUMEN}

\begin{abstract}
Microestructura de quesos blancos turcos bajos en grasa producidos industrialmente, influencia de la homogenización de la crema.
\end{abstract}

Se estudia la microestructura y distribución de los glóbulos de grasa de quesos blancos turcos bajos en grasa. Quesos con reducida y baja cantidad en grasa fueron fabricados conteniendo entre el $1,5 \%$ y $0,75 \%$ de grasa de leche, respectivamente, y con cremas homogeneizadas y no homogeneizadas, en una planta de lácteos. Las cremas homogeneizadas y no homogeneizadas y el suero de los quesos se analizaron para determinar la distribución de los glóbulos de grasa y también se analizaron las características de la microestructura de muestras de queso. De acuerdo con los resultados, la homogeneización de la crema reduce el tamaño de los glóbulos de grasa, mostrando un gran número de partículas de grasa dispersa en la matriz de caseína que mejoró la lubricación de la microestructura del queso. De acuerdo con las micrografías de la grasa que no se elimina, estas exhiben una matriz más amplia en la que hay pocos glóbulos de grasa en comparación con las micrografías de las muestras desgrasadas. La homogenización de la crema produce pequeños glóbulos de grasa y el suero resultante contiene glóbulos de grasa no incrustados. Estos resultados son importantes para los procesadores de productos lácteos, y muestran la utilidad de la homogeneización de crema como una herramienta del procesamiento a nivel industrial.

PALABRAS CLAVE: Crema homogeneizada - Microestructura - Queso blanco - Reducción de grasa

\section{SUMMARY}

Microstructure of industrially produced reduced and low fat Turkish white cheese as influenced by the homogenization of cream.

The microstructure and fat globule distribution of reduced and low fat Turkish white cheese were evaluated. Reduced and low fat cheeses were manufactured from $1.5 \%$ and $0.75 \%$ fat milk respectively which were standardized unhomogenized and homogenized cream in a dairy plant. Homogenized and non-homogenized creams and cheese whey were analyzed for fat globule distribution and cheese samples were also analyzed for microstructure characteristics. According to the results, the homogenization of cream decreased the size of fat globules; and showed that a large number of fat particles were dispersed in the in matrix and improved the lubrication of cheese microstructure. According to the micrographs for the fat, which was not removed, they exhibited a more extended matrix with a few small fat globules compared to the defatted micrographs. Homogenization of cream produces small fat globules and unclustured fat globules were found in the resulting whey. These results are important for dairy processors for using cream homogenization as a processing tool at the industrial level.

KEY-WORDS: Fat reduction - Homogenized cream Microstructure - White cheese.

\section{INTRODUCTION}

The homogenization of milk or cream decreases the fat globule size and homogenization has been used in the cheese industry especially to increase yield and rate of lipid hydrolysis (Madadlou et al., 2007; Rudan et al., 1998). However, the homogenization of milk adversely affects the structure of rennet gel and milk proteins in commercial practice and the concept of homogenizing only the cream portion of cheese milk was studied. Recently there have been many reports on the use of cream homogenization as a processing tool to enhance the properties of different types of cheese (Madadlou et al., 2007; Rudan et al., 1998; Poduval and Mistry, 1999; Metzger and Mistry, 1994; 1995).

Turkish white cheese is a brined cheese variety which is the most commonly consumed cheese in Turkey (Temelli et al., 2006). It is made from heattreated milk ripened slowly to improve flavor (Akın et al., 2003). In this study, the homogenization of cream was used as a processing tool at the industrial level, in order to reduce the ripening time for economic reasons.

The arrangement of casein particles, fat globules, dispersed water and mineral components on the micron scale is known as the microstructure of cheese (Ong et al., 2011). The microstructure is not a static concept; but evolves throughout the cheese processing steps (Pereira et al., 2009). Also, the microstructure of cheese significantly affects its final product processing characteristics, flavor and also textural properties (Noronha et al., 2008). Every cheese variety has different characteristic structural features that represent the chemical and biochemical changes in the cheese (Madadlou et al., 2005). 
Accordingly, the microstructure of white cheese (Madadlou etal.,2005;2006; Lobato-Calleros etal.,2007; Mcmahon et al., 2009; Karami et al., 2008; 2009; Akalın and Karaman, 2010; Ozer et al., 2003) and the microstructure of various cheeses produced by homogenized cream (Madadlou et al., 2007; Rudan et al., 1998; Poduval and Mistry, 1999; Metzger and Mistry, 1994; 1995) have been studied by many researchers. However, no information is available on the effect of cream homogenization on the microstructural properties of reduced and low fat Turkish white cheese. Therefore, the objective of this research was to investigate the effect of cream homogenization on the microstructure properties of reduced and low fat Turkish white cheeses at the $1^{\text {st }}$ day of ripening.

\section{MATERIALS AND METHODS}

\subsection{Milk and cheese}

Raw cows' milk containing $3.45 \%$ milk fat was obtained from and processed at the Pinar Dairy Products Company, Izmir, Turkey. Four different kinds of cheese from reduced-fat milk (CRF, HRF, CLF, and HLF) were prepared according to Figure 1. Then, the milk was pasteurized at $74^{\circ} \mathrm{C}$ for $15 \mathrm{~s}$ in a HTST system and cooled to $33^{\circ} \mathrm{C}$. The milk was inoculated by a sachet of direct-to-vat single culture containing Lactobacillus casei ssp. Casei and 0.5\% reactivated Redi-set mixed culture containing Lactococcus lacti sssp. Lactis and L. lactis ssp. Cremoris (DaniscoCo., Langebrogade 1, Copenhagen, Denmark), and then supplemented with a $\mathrm{CaCl}_{2}$ solution $(0.02 \% \mathrm{w} / \mathrm{v})$. It was held at $33^{\circ} \mathrm{C}$ for approximately $15 \mathrm{~min}$ for starter maturation (until pH 6.30) and then the liquid calf rennet (Ecoren 200, Maysa, Istanbul, Turkey) was added. The curd was allowed to set for 65-75 min and following coagulation, the curd was cut into approximately $1 \mathrm{~cm}^{3}$ cubes with vertical and horizontal knives. After being cut, the curd was left to settle for $30 \mathrm{~min}$. The curd was then mixed for 15 min to facilitate whey expulsion and transferred into the blocking machine. Following this procedure, the curds were molded in the polyethylene (PE) blocks $(300 \mathrm{~g})$ and the whey was moved on the conveyor. The cheeses in PE blocks were left in a cooling room $\left(+4^{\circ} \mathrm{C}\right)$ until the $\mathrm{pH}$ dropped to 4.75 . Then,

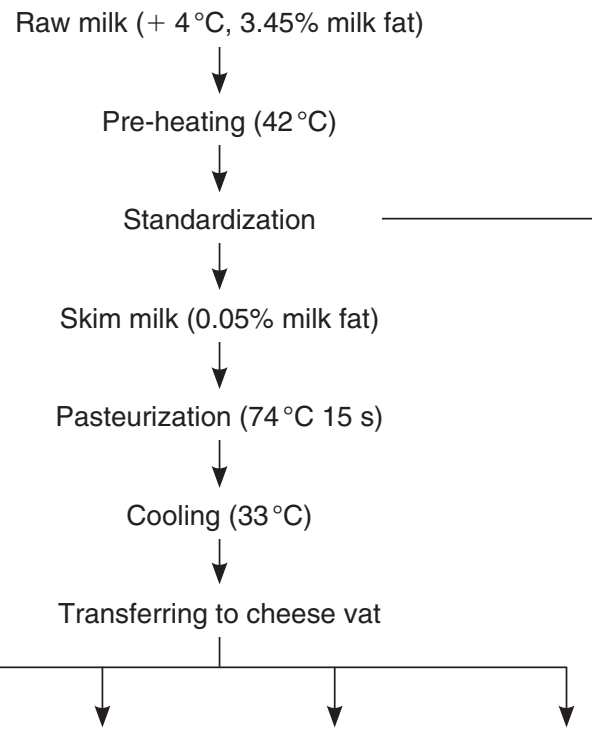

Skim milk (0.5\%) Skim milk (0.5\%) Skim milk $(0.5 \%) \quad$ Skim milk $(0.5 \%)$
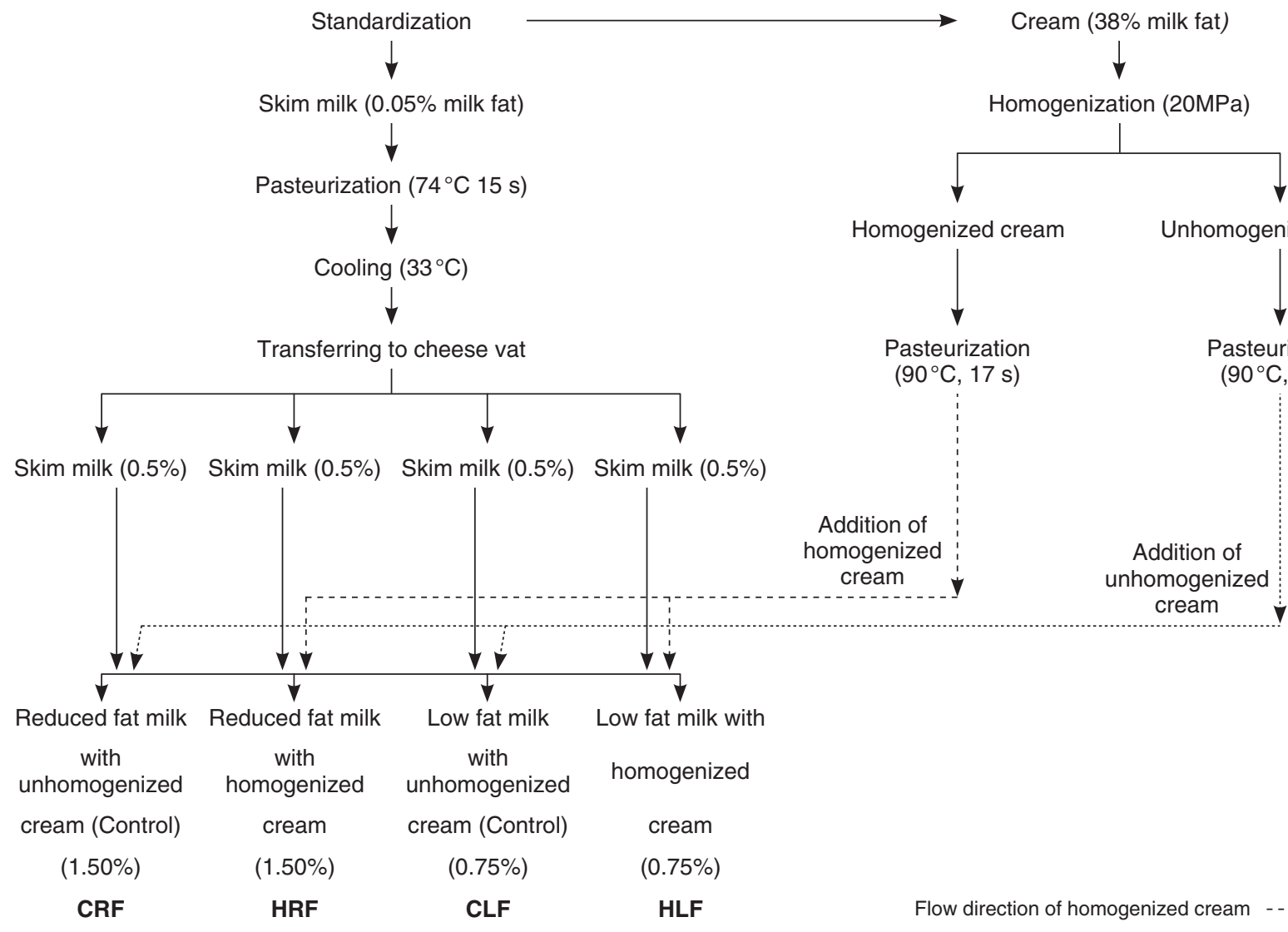

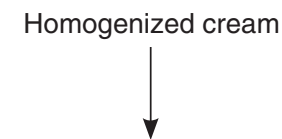

Pasteurization

$\left(90^{\circ} \mathrm{C}, 17 \mathrm{~s}\right)$
Unhomogenized cream

Pasteurization $\left(90^{\circ} \mathrm{C}, 17 \mathrm{~s}\right)$

Figure 1

Flow sheet for the preparation of cheese milks. 
the cheese blocks were covered with a brine solution $\left(15 \%\right.$ brine $\left.\mathrm{NaCl}, \mathrm{w} / \mathrm{v}, 15^{\circ} \mathrm{C}\right)$ for $300 \mathrm{~min}$ and stored at $4 \pm 2^{\circ} \mathrm{C}$ for approximately $500 \mathrm{~min}$. The cheese blocks were removed from the PE blocks. Subsequently, the cheese blocks were packaged in the vacuum sealed plastic pouch (BK3550, Cryovac, Sealed Air Corporation, U.K.) and stored at $4 \pm 2{ }^{\circ} \mathrm{C}$ at Pinar Dairy Company, Izmir, Turkey.

\subsection{Chemical analyses}

Dry matter, fat and protein contents were determined in the cheese whey obtained from the reduced and low fat treatments (Anonymous, 1994).

\subsection{Fat Globule Distribution}

The fat globules of reduced and low fat whey, homogenized and unhomogenized cream samples were viewed and photographed using an Olympus Light Microscope attached to a camera (CX21FS1, Olympus Optical Co., Tokyo, Japan) using a modified method by Metzger and Mistry (1995).

\subsection{Microstructure}

The cheese samples were prepared for scanning electron microscopy (SEM) at the $1^{\text {st }}$ day of ripening following a modified method by Hayat (1981) and Khosrowshahi et al. (2006). Micrographs of normal and defatted samples were selected for presentation at a magnification of 2500 or $3000 \mathrm{x}$.

\subsection{Statistical analysis}

An experimental design was conducted to evaluate the influence of cream homogenization on the chemical characteristics of reduced and low fat white cheese whey. One way analysis of variance for the data of chemical analyses was carried out. Significant means were compared using the Duncan test on the level of $P<0.05$. All the statistical analyses were conducted using the SPSS (Version 11.0) commercial statistical package (Kocabas et al., 1998; Dinkci et al., 2011).

\section{RESULTS AND DISCUSSION}

\subsection{Composition of cheese whey}

The average composition of the whey obtained from the reduced and low-fat Turkish white cheese from different treatments is given in Table 1.

Whey from the homogenized treatments has lower fat content than their corresponding controls $(P<0.05)$. In other words, fat transition to the whey was greater with CLF and CRF than with the HLF and HRF, respectively. So, it can be said fat loss in cheese manufacturing was decreased by homogenization of the cream.

As expected, homogenization of the cream significantly reduced the size of fat globules in Turkish white cheese milk. The difference between the homogenized treatment and the controls was likely to come from the fat particle clustering that occurred in the homogenized treatments. However, fat losses to the whey were of the same ratio $(0.02 \%)$ between low fat treatments (CLF and HLF) and reduced fat treatments (CRF and HRF), respectively.

Rudan et al. (1998) reported that whey obtained from homogenized milk has a higher fat content than the control while whey from the mixture of homogenized cream and milk has a lower fat content than the control. Similar to our results, the authors reported that homogenization of cream decreased the fat loss to the whey for reduced fat Mozzarella cheese.

As seen in Table 1, there was no significant difference in the dry matter between whey samples obtained from controls or whey from homogenized treatments $(P>0.05)$. However, the levels of dry matter content of the homogenized treatment cheese whey became gradually lower than the control. A similar decrease was obtained in the cheddar cheese whey which was produced with homogenized cream compared to the control by Nair et al. (2000).

On the other hand, the protein content of homogenized cream reduced fat whey was higher than the control $(P<0.05)$. Similar to other reports (Nair et al., 2000; Rudan et al., 1998) there were no differences between the protein contents of whey from HLF and CRF.

Table 1

Compositions of whey

\begin{tabular}{lcccc}
\hline \multicolumn{1}{c}{ Treatment $^{\mathrm{a}}$} & CLF & HLF & CRF & HRF \\
\hline Dry matter, \% & $5.96 \pm 0.01 \mathrm{~A}$ & $5.88 \pm 0.00 \mathrm{~B}$ & $5.97 \pm 0.05 \mathrm{~A}$ & $5.89 \pm 0.01 \mathrm{~B}$ \\
Fat, \% & $0.05 \pm 0.01 \mathrm{~B}$ & $0.03 \pm 0.01 \mathrm{C}$ & $0.07 \pm 0.01 \mathrm{~A}$ & $0.05 \pm 0.00 \mathrm{~B}$ \\
Protein, \% & $1.43 \pm 0.18 \mathrm{C}$ & $1.70 \pm 0.27 \mathrm{C}$ & $2.41 \pm 0.09 \mathrm{~B}$ & $2.95 \pm 0.45 \mathrm{~A}$ \\
\hline
\end{tabular}

${ }^{a}$ CRF: Reduced-fat white cheese whey manufactured from nonhomogenized cream containing $1.5 \%$ milk fat. HRF: Reduced-fat white cheese whey manufactured from homogenized cream containing $1.5 \%$ milk fat. CLF: Low-fat white cheese whey manufactured from nonhomogenized cream containing $0.75 \%$ milk fat. HLF: Low-fat white cheese whey manufactured from homogenized cream containing $0.75 \%$ milk fat. $A, B, C$ : Means in the same row bearing a common superscript differ significantly $(P<0.05)$. 
This type of whey composition of homogenized treatments is related to the compositions of cheeses with the homogenization of cream. The homogenization treatment of reduced and low fat cheeses resulted in a higher fat content, dry matter and free fatty acid (FFA) compared to the controls ( $1^{\text {st }}$ day not shown, in Karaman, 2007).

\subsection{Fat Globule Distribution}

Fat globules in the homogenized and unhomogenized creams are shown Figures $3 a$ and $3 \mathrm{~b}$. The control cream had larger fat globules, but the homogenized cream had small fat globules. Additionally, homogenized cream has clustered fat globules despite the fact that the other one hasn't. According to Figs. 3a and b, homogenized cream has different size fat globules; unhomogenized cream has approximately smaller sizes. So, an important feature of the photos is that the fat globules decreased drastically in size due to homogenization.

It was also determined that fat globules have uniformly, unclustured and irregular distribution. Figures 4 and 5 shows whey from cheeses made from CRF, HRF and CLF, HLF respectively. The fat globules in all cases were unclustered but the globules in the whey from the cheese from unhomogenized cream (CRF, CLF) were larger than the homogenized cream (HRF, HLF). The presence of tiny unclustured fat globules in the cheeses (Figures 6a, b, c, d) and whey (Figure $4 b, 5 b$ ) is evidenced.

According to Metzger and Mistry (1995) the control cream of reduced fat Mozzarella cheese contained fat globules whcih were unclustured and large, but homogenized cream had fat globules which were small and clustered. Similar to our results, same researchers obtained an unclustered fat globule distribution in whey from Mozzarella cheese made with the control and homogenized cream.

The homogenization of cream or milk reduced the size of fat globules and made important changes in the milk fat globule membrane (Rudman et al., 1998; Nair et al., 2000). So, before cream homogenization, the fat globule sizes were distributed uniformly in the cheese milk (Figure 2). After homogenization their sizes were decreased in the cream (Figure $3 b$ ) and also in the whey (Figure 4b, 5b).

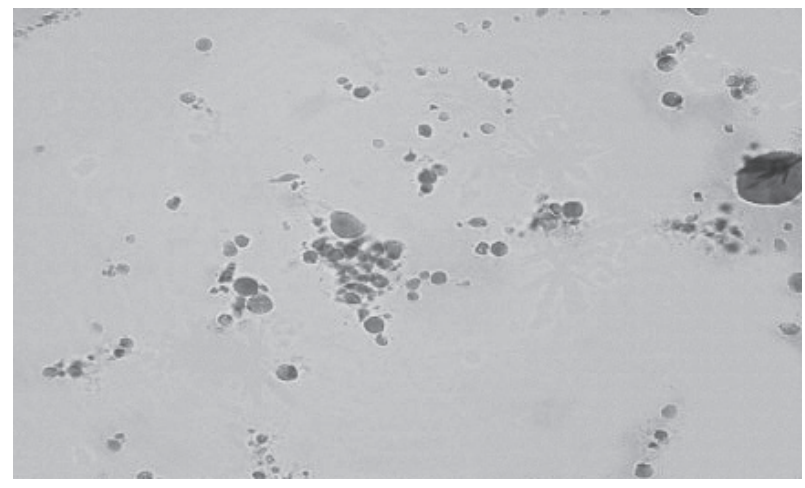

Figure 2

Fat globule distribution in whole milk.
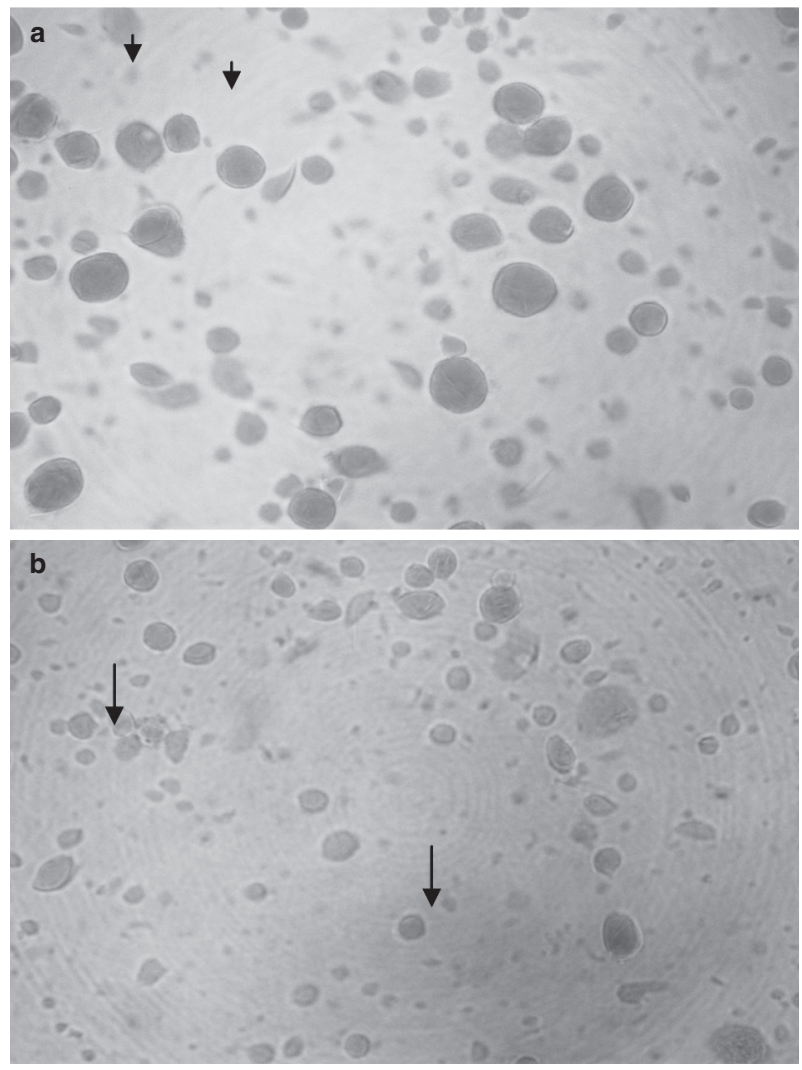

Figure 3

Fat globule distribution in a) the control cream b) homogenized cream.
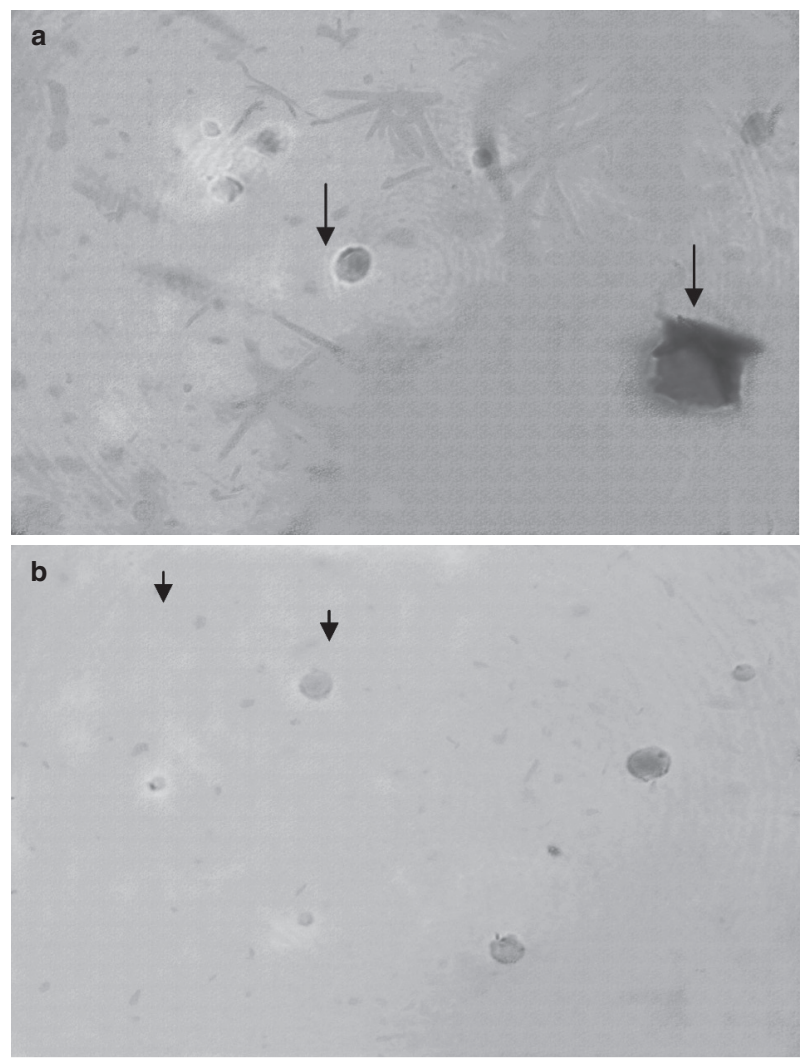

Figure 4

Fat globule distribution in a) the control skim milk standardized to $1.5 \%$ fat with unhomogenized cream $\mathbf{b}$ ) the control skim milk standardized to $1.5 \%$ with homogenized cream. 

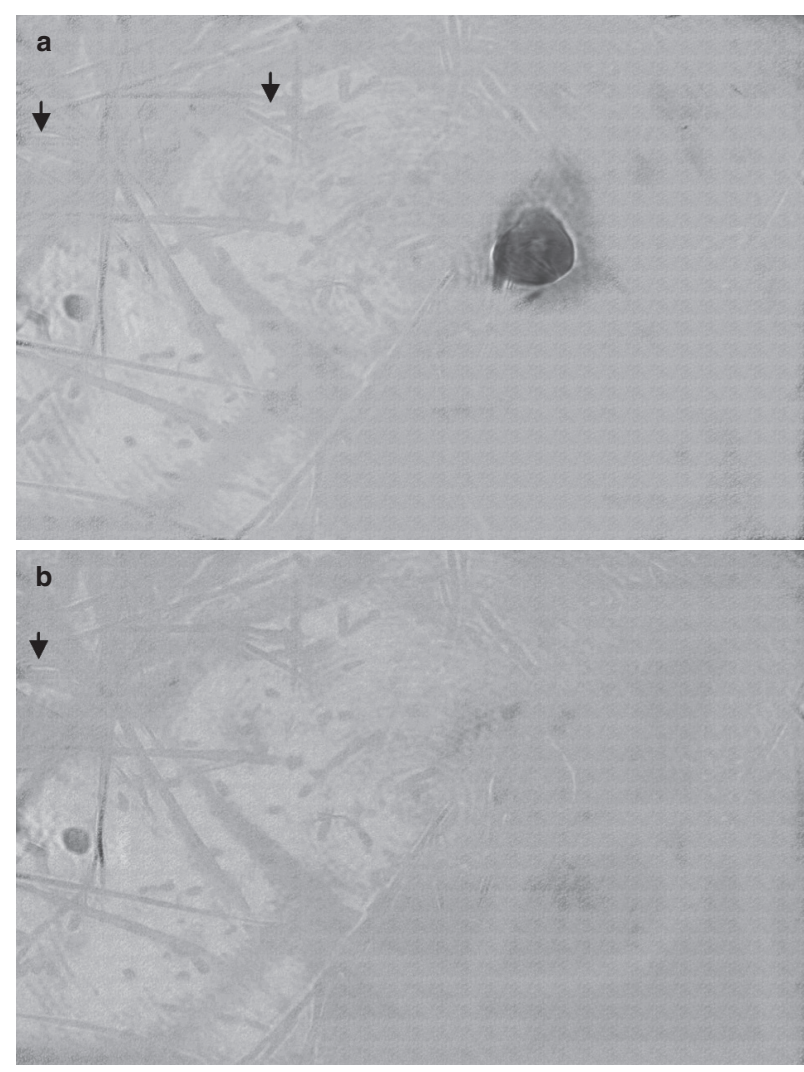

Figure 5

Fat globule distribution in a) the control skim milk standardized to $0.75 \%$ fat with unhomogenized cream b) the control skim milk standardized to $0.75 \%$ fat with homogenized cream.

\subsection{Microstructure}

The differences between reduced and low fat Turkish white cheeses manufactured from homogenized and non-homogenized cream could be visually observed in images obtained by defatted and normal SEM (Figure 6).

In the micrographs of the defatted samples, the microstructure of reduced and low fat control cheeses showed a dense fibrous protein matrix interspread with irregular surfaced cavities of different sizes. This compactness of the network indicates a removal of fat and serum during serum preparation. Therefore, the control cheese possibly has a denser microstructure with larger protein compared with the homogenized treatments. In other words, verifying the data in Table 1, fat loss to the whey was decreased by the homogenization of cream. In cheeses from homogenized cream (Figures $6 a, 6 c$ ), large numbers of fat particles were dispersed in the casein matrix. In these samples, the protein matrix was dispersed with a large number of small fat globules. Subsequently, small fat globules in the protein matrix improve the lubrication of homogenized cream cheeses. There were also very few small and irregularly shaped cavities. So, homogenization of the cream in reduced and low fat white cheeses resulted in smaller, more dispersed fat globules in the cheese and caused a slightly softer structure. This type structure of homogenized treatments corroborated the extensive elastic characteristic which was described by the consumer taste panel and the textural analysis, especially for hardness. The homogenization treatment of reduced and low fat cheeses resulted in a lower hardness compared to the controls $\left(1^{\text {st }}\right.$ day of dates $2.84,2.98,3.02,3.22$ for HRF, CRF, HLF, CLF, respectively, all data not shown, in Karaman, 2007). Similar results were also reported by Madadlou et al. (2007); Metzger and Mistry (1994); Metzger and Mistry (1995) for white cheese and cheddar cheese, respectively.

On the other hand, the protein matrix in the control cheese of low fat cheese (Figure 6b1) was dispersed with less fat than that in the reduced fat cheese (Figure 6b). This may be explained by a decreased fat content or increased protein contents that lead to a hard and crumbly cheese. Similar results were obtained by Meztger and Mistry (1995) for reduced fat cheddar cheese manufactured from homogenized cream or milk Emmons et al. (1980).

Madadlou et al. (2007) also reported that cream homogenization had a significant influence on the microstructure of the low fat Iranian white cheese. Similar to our results, same researchers reported from the micrographs of the cheeses of homogenized treatments that a large number of small fat particles was embedded in the casein matrix, improving the lubrication of these cheeses.

In the micrographs of normal cheeses (fat not removed), all samples exhibited a more extended matrix with few small fat globules compared to the defatted micrographs (Figure 6c, c1, d, d1). Similar to our results, the differences between the defatted and normal micrographs of Turkish white cheeses were observed by Akalın and Karaman (2010).

\section{CONCLUSIONS}

The study indicated that cream homogenization had major effects on the microstructure and fat globule distribution of reduced and low fat Turkish white cheeses. Defatted scanning electron microscopy demonstrated that homogenization of the cream decreased the size of fat globules and showed a large number of fat particles were were dispersed in the casein matrix. According to the fat not removed micrographs, they have exhibited a more extended matrix with few small fat globules compared to the defatted micrographs. Homogenization of the cream produces small fat globules and unclustured fat globules in the resulting whey. These findings are important for using cream homogenization as a processing tool at the industrial level.

\section{ACKNOWLEDGMENTS}

The authors thank the Pinar Dairy Products Company, Izmir, Turkey; Turkish Scientific and Technological Research Council (TUBITAK) Ankara and Ege University Scientific Research Fund, İzmir, Turkey for funding this project. 

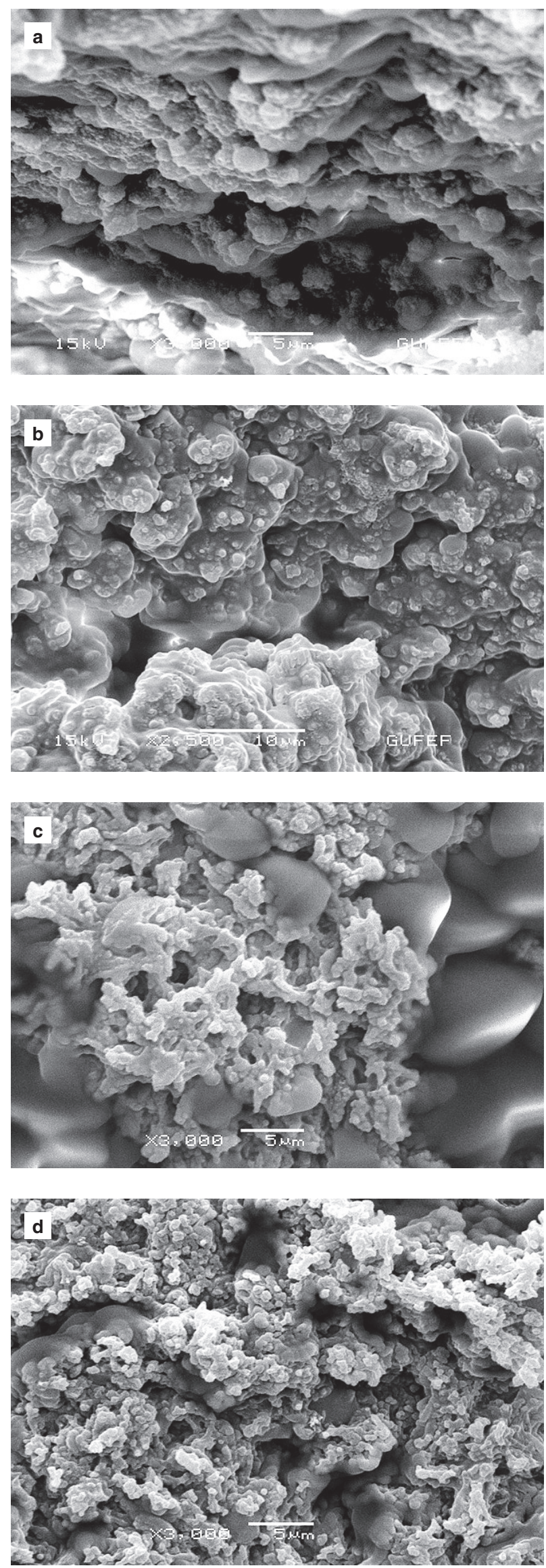
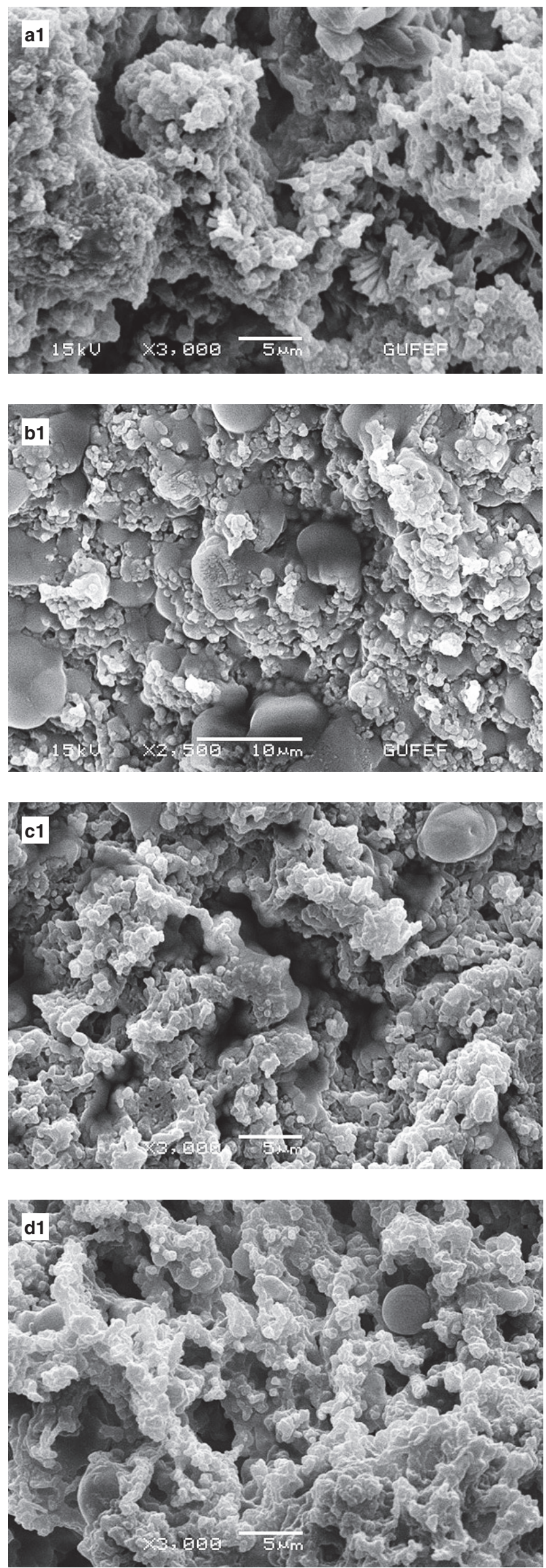

Figure 6

Scanning electron micrographs of reduced fat $(\mathbf{a}, \mathbf{c})$, reduced fat control (a1, c1), low fat (b, d) and low fat control (b1, d1) Turkish white cheeses. The micrographs show appearances of defatted samples a, a1, b, b1 and normal samples c, c1, d, d1. 


\section{REFERENCES}

Akalın SA, Karaman, DA. 2010. Influence of packaging conditions on the textural and sensory characteristics, microstructure and color of industrially produced Turkish white cheese during ripening. J. Texture Studies, 41, 549-562.

Akın N, Aydemir S, Kocak C, Yıldız MA. 2003. Changes of free fatty acid contents and sensory properties of white pickled cheese during ripening. Food Chem. 80, 77-83.

Anonymous, 1994. TS 1018. Çiğ Süt Standardı. Türk Standartları Enstitüsü. Ankara, Turkey.

Dinkci N, Kesenkas H, Seckin AK, Kınık O, Gonc S. 2011. Influence of a vegetable fat blend on the texture, microstructure and sensory properties of Kashar cheese. Grasas Aceites 62, 275-283.

Emmons DB, Kalab M, Larmond E. 1980. Milk gel structure. X. Texture and Microstructure in Cheddar cheese made from whole milk and from homogenized low-fat milk. J. Texture Studies, 11, 15-34.

Hayat MA. 1981. Principles and techniques of electron microscopy. Vol. 1. Edward Arlond Lt., London, 522P.

Karaman DA. 2007. Effect of cream homogenization on the manufacture and characteristics of the reduced fat white cheese. PhD Thesis in Dairy Technology, Ege University, Izmir, Turkey, 222 pages.

Karami M, Ehsani MR, Mousavi SM, Rezaei K, Safari M. 2009. Changes in the rheological properties of Iranian UFfeta cheese during ripening. Food Chem. 112, 539-544.

Karami M, Ehsani MR, Ebrahimzadeh Mousavi M, Rezaei K, Safari M. 2008. Microstructural changes in fat during the ripening of Iranian ultrafiltered Feta cheese. J. Dairy Sci. 91, 11, 4147-4154.

Khosrowshahi A, Madadlou A, Mousavi EM, EmamDjomeh Z. 2006. Monitoring the chemical and textural changes during ripening of Iranian white cheese made with different concentrations of starter. J. Dairy Sci. 89, 3318-3325.

Kocabas, Z, Odabası, S, Atamer, M. 1998. Mikrobiyolojik verilerin istatistiksel analizinde uygun transformasyon yönteminin seçimi. Gıda. 23, 1, 11-17.

Lobato-Calleros C, Reyes-Hernandez J, Beristain $\mathrm{Cl}$, Homelas-Uribe Y, Sanchez-Garcia JE, Vernon-Carter EJ. 2007. Microstructure and texture of white fresh cheese made with canola oil and whey protein concentrate in partial or total replacement of milk fat. Food Research Int. 40, 529-553.

Madadlou A, Mousavi ME, Khosrowshahi Asl A, EmamDjome Z., Zargaran M. 2007. Effect of cream homogenization on textural characteristics of low-fat Iranian white cheese. Int. Dairy J. 17, 547-554.

Madadlou A, Khosrowshahi A, Mousavi AM, Djome ZE. 2006. Microstructure and rheological properties of Iranian white cheese coagulated at various temperatures. J. Dairy Sci. 89, 2359-2364.
Madadlou A, Khosrwoshahi A, Mousavi ME. 2005. Rheology, microstructure and functionality of low-fat Iranian White cheese made with different concentrations of rennet. J. Dairy Sci. 88, 3052-3062.

Mcmahon DJ, Motawee MM, Mcmanus WR. 2009. Influence of brine concentration and temperature on composition, microstructure, and yield of feta cheese. J. Dairy Sci. 92, 4169-4179.

Metzger LE, Mistry VV. 1995. A new approach using homogenization of cream in the manufacture of reduced fat cheddar cheese. 2. Microstructure, fat globule distribution, and free oil. J. Dairy Sci. 78, 1883-1895.

Metzger LE, Mistry VV. 1994. A new approach using homogenization of cream in the manufacture of reduced fat cheddar cheese. 1. Manufacture, Composition and Yield. J. Dairy Sci. 77, 35063515.

Nair MG, Mistry VV, Oommen BS. 2000. Yield and functionality of cheddar cheese as influenced by homogenization of cream. Int. Dairy J. 10, 647657.

Noronha N, Duggan E, Ziegler GR, Stapleton JJ, O'riordan ED, O'sullivan M. 2008. Comparison of microscopy techniques for the examination of the microstructure of starch-containing imitation cheeses. Food Research Int. 41, 472-479.

Ong L, Dagastine RR, Kentish SE, Gras, SL. 2011. Microstructure of milk gel and cheese curd observed using cryo scanning electron microscopy and confocal microscopy. LWT - Food Sci. Technol. 44, 1291-1302.

Ozer BH, Robinson RK, Gradison SA. 2003. Textural and Microstructural Properties of Urfa Cheese (A Traditional White Brined Turkish Cheese). Int. J. Dairy Tech. 56, 171-176.

Pereira Cl, Gomes AMP, Malcata FX. 2009. Microstructure of cheese: Processing, technological and microbiological considerations. Trends in Food Sci. Technol. 20, 213-219.

Poduval VS, Mistry VV. 1999. Manufacture of reduced fat mozzarella cheese using ultrafiltered sweet buttermilk and homogenized cream. J. Dairy Sci. 82, 1-9.

Rudan MA, Barbano DM, Guo RM, Kindstebt PSK. 1998. Effect of modification of fat particle size by homogenization composition, proteolyses, functionality and appearance of reduced fat mozzarella cheese. J. Dairy Sci. 81, 2065-2076.

Temelli S, Anar S, Sen C., Akyuva P. 2006. Determination of microbiological contamination sources during Turkish white cheese production. Food Control, 17, 856-861.

Recibido: $7 / 10 / 11$ Aceptado: 24/1/12 